\title{
THE EFFECT OF GOLD PRICE CHANGES, USD/IDR EXCHANGE RATE CHANGES AND BANK INDONESIA (BI) RATE ON JAKARTA COMPOSITE INDEX (JCI)'S RETURN AND JAKARTA ISLAMIC INDEX (JII)'S RETURN
}

\author{
Robiyanto Robiyanto \\ Faculty of Economics and Business Satya Wacana Christian University Salatiga 50711, Central Java, Indonesia \\ Email: robiyanto@staff.uksw.edu
}

\begin{abstract}
This study examines the effect of gold price (in Rupiah) changes, US Dollar exchange rate changes against Rupiah (USD / IDR), and BI rate on Jakarta Composite Index (JCI) return and Jakarta Islamic Index (JII) return in Stock Exchange Indonesia during the period of June 2008 to September 2017. The data used in this study was obtained from the official website of Bank Indonesia and Bloomberg. Data analysis was done by using multiple regression techniques by previously doing classical assumption test. The result of this research is that the exchange rate of USD / IDR changes and BI rate has a significant negative effect on JCI return.
\end{abstract}

Keywords: USD/IDR exchange rate, gold price, BI rate, Jakarta Composite Index (JCI), Jakarta Islamic Index (JII).

\section{Introduction}

Many factors affect the movement of the stock market in Indonesia. These factors can be external factors (i.e., world financial market movements) as well as internal factors (i.e., Indonesian macro indicators). Associated with these factors, many studies have attempted to conduct studies, such as research conducted by Gumilang, Hidayat, and NP (2014); Haholongan (2016); Harmono (2017); Hersugondo, Robiyanto, Wahyudi, and Muharam (2015); Kurniawati (2015); Triyono and Robiyanto (2017); Uligoma (2014); Yuswandy (2013).

Gumilang et al. (2014) conducted a study on the effects of macroeconomic variables, gold prices, and world oil prices on the Jakarta Composite Index (JCI). The results showed that the interest rate, exchange rate, world oil price and gold price have a significant influence on JCI. The interest rate, the exchange rate, and the world oil price have a negative influence on JCI while the gold price has a positive influence on JCI. In line with the study, Uligoma (2014) found that there is a negative relationship between JCI and foreign exchange rate. This is also supported by the results of research conducted by Yuswandy (2013), which specifically examines individual stocks. While Hersugondo et al. (2015) examine the effect of world oil prices on JCI and find that oil prices have no significant effect on JCI. Meanwhile, Kurniawati (2015) specifically conducted a review of the banking sector and found that interest rates had a significant negative effect on banking sector stocks.
From the elucidation of those previous studies, it can be seen that those previous studies focus on JCI as well as individual and sectoral stocks. It is still rare to find a study that specifically conducts studies on the Jakarta Islamic Index (JII). Stocks that included into JII calculations have special characteristics. Some of these characteristics such as operational activities and products/services produced are by the principles of sharia and have an Obligation Asset Ratio of not more than $90 \%$. Therefore, this study not only conducted a study on JCI but also conducted a study on JII. The independent variables used are gold price, USD/IDR rate, and Bank Indonesia interest rate.

The purpose of this research is to know the influence of gold price, USD/IDR rate, and Bank Indonesia interest rate on the JCI and JII. This research is expected to provide input for stock investors in general, as well as stock investors who prioritize sharia aspects in investing in Indonesia Stock Exchange.

\section{Jakarta Composite Index (JCI)}

The Jakarta Composite Index (JCI) was first introduced on April 1, 1983. While August 10, 1982, is the day for the calculation basis with a value of one hundred. JCI is an indicator of stock price movements listed on the Indonesia Stock Exchange (or Jakarta/JSX Stock Exchange at JCI introduced), The formula used to calculate the JCI is Paasche formula as follows (Ang, 1997): 


$$
J C I=\frac{\sum\left(P_{S} \times S_{S}\right)}{\sum\left(P_{b a s e} \times S_{S}\right)}
$$

Whereas:

JCI : Jakarta Composite Index

$P_{s}:$ Stock price

$S_{S} \quad:$ Outstanding shares

$P_{\text {base }}$ : Stock base price

The upward JCI indicates that the Indonesian stock market (in this case the Indonesia Stock Exchange) is being excited if JCI is stagnant or unchanged it indicates that a stable market situation and if JCI points to a decline means sluggish market conditions.

\section{Jakarta Islamic Index (JII)}

On July 3, 2000, the Indonesia Stock Exchange introduced the Jakarta Islamic Index (JII). JII was formed to guide investors interested in investing in stocks listed on the Indonesia Stock Exchange by prioritizing the principles of sharia. JII is calculated from thirthty shares of companies that have operations that are not contrary to Islamic law (Robiyanto, 2017b). There are several criteria for a share to be included in JII calculations, some of which are not involving usury (as found in conventional banking), the company does not conduct distribution activities, produce and provide services that do not violate Islamic law (e.g. cigarettes, alcoholic beverages and so forth). In addition to this, the Indonesia Stock Exchange also set some criteria such as shares listed on the Indonesia Stock Exchange for at least three months; the Obligation Asset Ratio (not more than 90\%); criteria of market capitalization; and liquidity criteria (Ernayani, Robiyanto, \& Sudjinan, 2017). The Indonesia Stock Exchange conducts a review of the shares that enter the JII calculation once every six months.

\section{Hypothesis Development}

\section{Gold}

Gold is a chemical element found in the periodic table with the Au (Latin: 'aurum') with atomic number 79. Tully and Lucey (2007) argue that gold is a precious metal that can be classified as a commodity and monetary assets. Gold can be used as a store of wealth throughout the history of the world because of its durability (Batten, Ciner, \& Lucey, 2010; Baur \& McDermott, 2009; Beckmann \& Czudaj, 2012) and accepted universally (Kumar, 2014; Robiyanto, Wahyudi, \& Pangestuti, 2017b).
Gold is also used as a financial standard in many countries even used as jewelry, and commodities for the electronics industry. The use of gold in the field of monetary and financial is based on the absolute monetary value of gold itself against various currencies around the world (Tully \& Lucey, 2007). Forms of use of gold in the field of monetary are typically in the form of bullion or gold bars in various units of grams to kilograms weight. In international commodity markets, in addition to being traded in the spot market, gold is also traded on the futures market.

Several studies have linked gold with the stock market, for example, research conducted by Gumilang et al. (2014); Ibrahim (2012); Ibrahim and Baharom (2012). Ibrahim and Baharom (2012) found that gold has a positive relationship with Kuala Lumpur Composite Index (KLCI) in Malaysia. This finding supported by Ibrahim (2012), which concluded that gold could be an alternative investment for the stock market in Malaysia. While, Gumilang et al. (2014) found that the price of gold has a significant positive effect on the JCI in Indonesia. This indicates that the increasing price of gold could increase the stock price in Indonesia Stock Exchange. Hence, according to Gumilang et al. (2014), rising gold prices would boost the profitability of mining stocks on the Indonesia Stock Exchange.

Research conducted by Robiyanto, Wahyudi, and Pangestuti (2017a) also found that gold has a significant positive relationship with JCI which is a stock market indicator in Indonesia. The same is true of stock markets in Singapore, Thailand, and the Philippines. Based on the above, the hypothesis is formulated as follows:

$H_{l a}$ : Gold price changes have a positive effect on the Jakarta Composite Index (JCI)'s return

$H_{l b}$ : Gold price changes have a positive effect on the Jakarta Islamic Index (JII)'s return

\section{USD/IDR Exchange Rate}

The exchange rate is the amount of a particular currency that can be exchanged for a unit of another currency (Joesoef, 2008). Related to exchange rates, Nuryadin and Santoso (2004) suggest that in the monetary or asset view, the exchange rate will tend toward an international balance determined from the interaction of demand and supply of money. Since August 14,1998 , the implementation of the free-floating exchange rate policy in Indonesia, the USD/ IDR exchange rate movement is completely free-floating. This increases the degree of uncertainty in the economy and business activities in Indonesia (Atmadja, 2002).

The exchange rate of USD/IDR may affect the capital market in Indonesia. Kurniawati (2015) for example, suggests that the exchange rate may affect the amount of costs to be incurred and the amount of 
costs to be earned in stock transactions and securities in the capital market. From the perspective of the company, assuming the company uses imported raw materials or financing in the form of United States Dollar (USD), the strengthening of the USD/IDR exchange rate will cause the company's burden to increase. Research results by Gumilang et al. (2014); Irianto (2002); Triyono and Robiyanto (2017); Uligoma (2014) shows that the exchange rate of USD/ IDR has a negative effect on the Jakarta Composite Index (JCI). Based on this then formulated the following hypothesis:

$H_{2 a}$ : The USD/IDR exchange rate has a negative effect on the Jakarta Composite Index (JCI)

$H_{2 b}$ : The USD/IDR exchange rate has a negative effect on the Jakarta Islamic Index (JII)

\section{Bank Indonesia's Rate}

The interest rate is the price in the form of the percentage of borrowed money to be paid over a period (Gumilang et al., 2014). Meanwhile, a more detailed definition of the interest rate of Bank Indonesia according to Kurniawati (2015) is a policy interest rate that reflects the stance or stance of monetary policy stipulated by Bank Indonesia and announced to the public (via the website of Bank Indonesia, i.e. www. bi.go.id). The BI Rate is announced by the Board of Governors of Bank Indonesia at each monthly Board of Governors Meeting and implemented in monetary operations conducted by Bank Indonesia through liquidity management in the money market to achieve the operational targets of monetary policy.

The increasing interest rates will make an investment in the capital market unattractive. This can happen because investors will be more likely to shift their investments in risk-free instruments if the risk-free instruments provide relatively acceptable results by investors compared to investment instruments such as stocks that contain greater risks (Ernayani, Sari, \& Robiyanto, 2017; Robiyanto, 2017a). Kurniawati (2015) and Irianto (2002) empirically proves that interest rates have a negative impact on JCI. The same is also found by Gumilang et al. (2014). Based on this then formulated the following hypothesis:

$H_{3 a}$ : BI rate has a negative effect on the Jakarta Composite Index (JCI)

$H_{3 b}$ : BI rate has a negative effect on the Jakarta Islamic Index (JII)

\section{Research Method}

\section{Data}

The data used in this research is time series data consisting of gold price data (denominated in $\mathrm{Ru}-$ piah), US Dollar exchange rate against Rupiah (USD/ IDR), BI rate and 7-days repo rate, Jakarta Composite
Index (JCI) at the Indonesia Stock Exchange and Jakarta Islamic Index (JII) on the Indonesia Stock Exchange during the period of June 2008 to September 2017. The data used in this study were obtained from the official website of Bank Indonesia and Bloomberg.

\section{Operational Definition of Variables}

The independent variable used in this research is the change of gold price (denominated in Rupiah) given GOLDIDR notation, change of US Dollar to Rupiah exchange rate given USDIDR notation, BI rate is given BI notation. While the dependent variable used in this study is the return of Jakarta Composite Index (JCI) in Indonesia Stock Exchange, and return Jakarta Islamic Index (JII) in Indonesia Stock Exchange.

The calculation of changes in the price of gold (denominated in Rupiah) / GOLD is as follows:

$\begin{array}{ll}\Delta \mathrm{GOLDIDR}= & \frac{\text { GOLDIDR }_{\mathrm{t}}-\text { GOLDIDR }_{\mathrm{t}-1}}{\text { GOLDIDR }_{\mathrm{t}-1}} \\ \text { Whereas, } & \\ \Delta \mathrm{GOLDIDR}_{t}: \begin{array}{l}\text { change of gold price (denominated in } \\ \text { Rupiah) in month } t \\ \text { gold price (denominated in Rupiah) }\end{array} \\ \text { GOLDIDR }_{t}: \begin{array}{l}\text { in month } t \\ \text { in }\end{array} \\ \text { GOLDIDR }_{t-1}: \begin{array}{l}\text { gold price (denominated in Rupiah) } \\ \text { in month } t-1\end{array}\end{array}$

The calculation of changes in the US Dollar exchange rate against Rupiah/USDIDR is as follows:

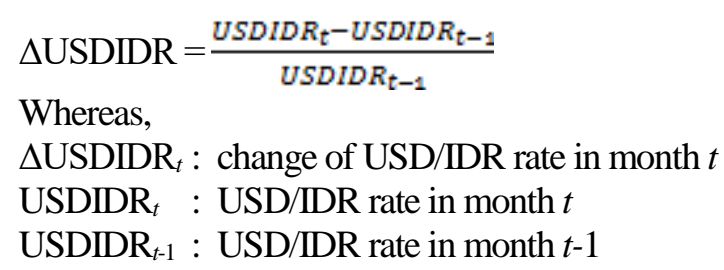

The BI rate (BI Rate) and 7-days repo rate use data obtained from the official website of Bank Indonesia (2017a). Effective since August 19, 2016, Bank Indonesia strengthened the monetary operations framework by introducing a new BI rate or BI rate policy, replacing the BI Rate even in the transitional period of the BI Rate (Harmono, 2017). In this research, BI rate (for period before August 2016) and the BI 7-Day Repo Rate which replacing BI rate (for period after August 2016) used as risk-free-rate proxy in this study.

The calculation of the return of the Jakarta Composite Index $(\triangle \mathrm{JCI})$ on the Indonesia Stock Exchange and the return of the Jakarta Islamic Index ( $\Delta$ JII) in the Indonesia Stock Exchange are as follows: 
$\Delta \mathrm{JCI}_{t}=\frac{J C I_{t}-J C I_{t-1}}{J C I_{t-1}}$

$\Delta \mathrm{JCI}_{t}: \mathrm{JCI}$ return in month $t$

$\mathrm{JCI}_{t}: \mathrm{JCI}$ in month $t$

$\mathrm{JCI}_{t-1}: \mathrm{JCI}$ in month $t-1$

$\Delta \mathrm{JI}_{t}=\frac{I I_{t}-J I_{t-1}}{J I_{t-1}}$

$\Delta \mathrm{JII}_{t}:$ JII return in month $t$

$\mathrm{JII}_{t} \quad: \mathrm{JII}$ in month $t$

$\mathrm{JII}_{t-1} \quad: \mathrm{JII}$ in month $t-1$

\section{Technique of Analysis}

Multiple regression analysis with Ordinary Least Square (OLS) method was used to analyze the data in this study. The regression equation used to examine the effect of changes in gold prices, changes in exchange rates and BI rate are as follows:

For JCI,

$\Delta \mathrm{JCI}_{t}=\alpha+\beta_{1} \Delta \mathrm{GOLDIDR}_{t}-\beta_{2} \Delta \mathrm{USDIDR}_{t}-\beta_{3} \mathrm{BI}_{t}+e$ Whereas,

$\Delta \mathrm{JCI}_{t} \quad:$ JCI return in month $t$

$\Delta \mathrm{GOLDIDR}_{t}$ : change of gold price (in Rupiah Currency) in month $t$

$\Delta \mathrm{USDIDR}_{t}:$ change of USD/IDR exchange rate in month $t$

$\mathrm{BI}_{t} \quad:$ BI rate in month $t$

$\alpha \quad$ : Constant

$\beta_{1}, \beta_{2}, \beta_{3} \quad:$ Regression coefficient

e : error

For JII,

$\Delta \mathrm{JII}_{t}=\alpha+\beta_{1} \Delta \mathrm{GOLDIDR}_{t}-\beta_{2} \Delta \mathrm{USDIDR}_{t}-\beta_{3} \mathrm{BI}_{t}+e$ Whereas,

$\Delta \mathrm{JII}_{t} \quad:$ JII return in month $t$

$\Delta \mathrm{GOLDIDR}_{t}$ : change of gold price (in Rupiah Currency) in month $t$

$\Delta$ USDIDR $_{t}:$ change of USD/IDR exchange rate in month $t$

$\mathrm{BI}_{t} \quad:$ BI rate in month $t$

$\alpha \quad$ : Constant

$\beta_{1}, \beta_{2}, \beta_{3} \quad:$ Regression coefficient

e : error

Before multiple regression analysis, classical assumption test such as residual normality test, multicollinearity test, heteroscedasticity test and autocorrelation test are done.

\section{Result and Discussion}

\section{Residual Normality Test Results}

The residual normality test is performed by looking at the histogram and pp-plot patterns of the standardized residual. If the histogram pattern follows the normal curve and the $p$ - $p$ plot follows the diagonal line, then it is stated that the standardized residual is normally distributed. The result of residual normality test for JCI and JII equation can be seen in Figure 1 and Figure 2. From Figure 1 and Figure 2 it is seen that the standardized residual equations of JCI and JII follow normal curve pattern, further pp plot of standardized residual equation JCI and JII also follows the diagonal line, so it can be concluded that the standardized residual equations JCI and JII are normally distributed.
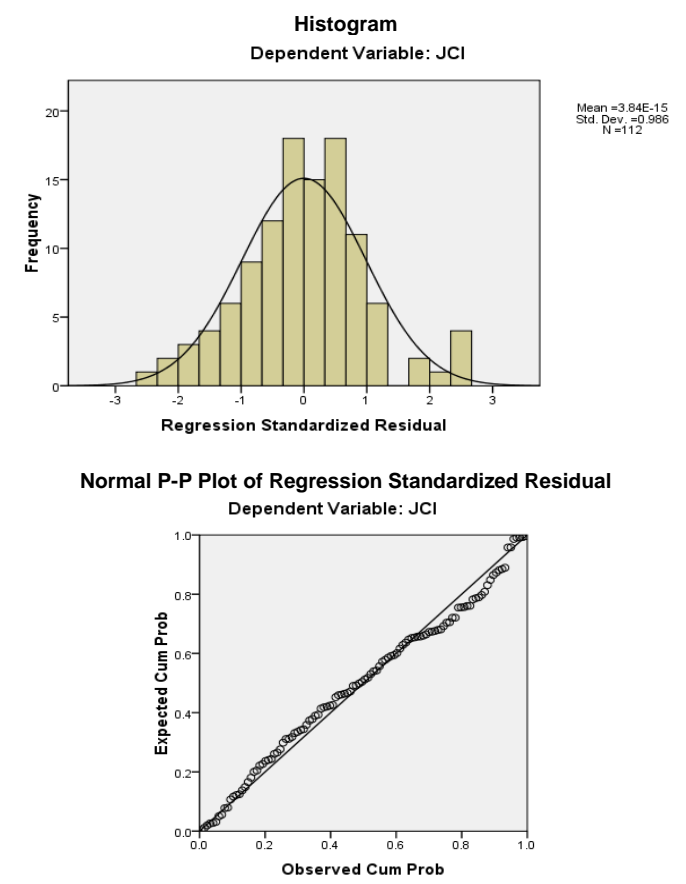

Figure 1. Histogram and normal $p$ - $p$ plot for standardized residual in JCI equation
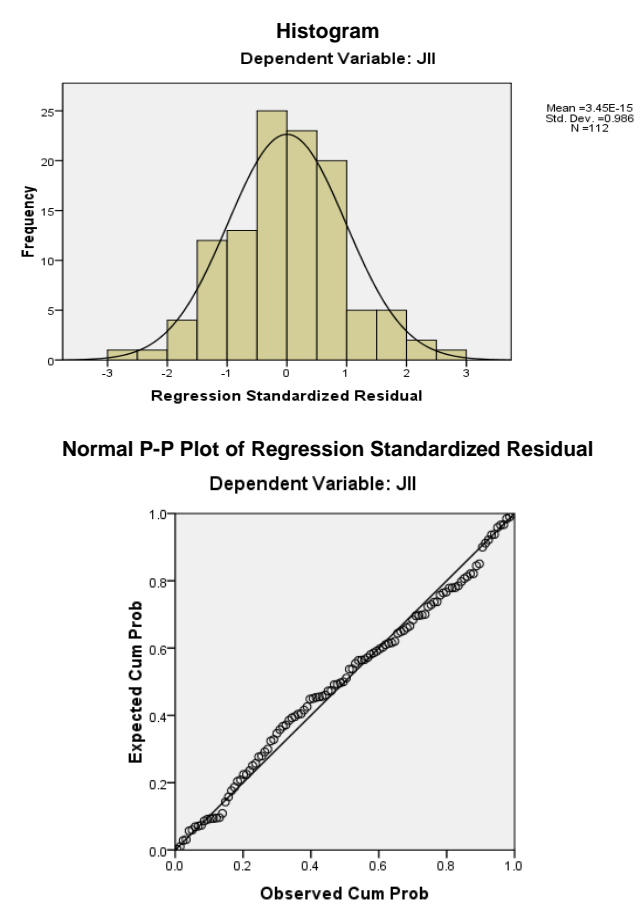

Figure 2. Histogram and normal $p-p_{1}$ plot for standardized residual in JII equation 


\section{Multicollinearity Test Results}

Multicollinearity test is done by looking at the value of Variance Inflation Factor (VIF), if found VIF value greater than 10 , then the regression equation indicated the existence of multicollinearity. In Table 1 we can see the VIF values for each variable in the regression equation used in this study.

Table 1

Multicollinearity Test Results for JCI and JII Regression Equations

\begin{tabular}{lc}
\hline \multicolumn{1}{c}{ Independent Variables } & VIF \\
\hline GOLDIDR & 1.107 \\
USDIDR & 1.148 \\
BI & 1.043 \\
\hline SO
\end{tabular}

Source: Bank Indonesia, 2017b; Bloomberg, 2017.

Based on Table 1, it can be seen that the independent variables of GOLDIDR, USDIDR, and BI either for JCI regression equation or JII regression equation do not have VIF value greater than 10 . There is no multicollinearity in JCI and JII regression equation.

\section{Heteroscedasticity Test Results}

The heteroscedasticity test was performed by the White test. If there are no independent variables (either in the normal form, quadratic or interaction) that have a significant effect on the residual squared value, then there is no heteroscedasticity in the model. In Table 2, we can see the results of heteroscedasticity test using White test for JCI and JII regression equation.

Table 2

White Test Results for JCI and JII Regression Equations

\begin{tabular}{lcc}
\hline Variable & $\begin{array}{c}\text { Probability } \boldsymbol{t} \text { - } \\
\text { value Coefficient } \\
\text { In JCI } \\
\text { Regression } \\
\text { Equation }\end{array}$ & $\begin{array}{c}\text { Probability } \boldsymbol{t} \text { - } \\
\text { value } \\
\text { Coefficient In } \\
\text { JII Regression } \\
\text { Equation }\end{array}$ \\
\hline C & 0.3179 & 0.1019 \\
GOLDIDR & 0.1161 & 0.3115 \\
GOLDIDR^2 & 0.6629 & 0.6422 \\
GOLDIDR*USDIDR & 0.7130 & 0.7416 \\
GOLDIDR*BI & 0.1345 & 0.3396 \\
USDIDR & 0.3414 & 0.2880 \\
USDIDR`2 & 0.1757 & 0.3113 \\
USDIDR*BI & 0.3866 & 0.2898 \\
BI & 0.3471 & 0.0981 \\
BI^2 & 0.3056 & 0.0672 \\
\hline SOUז'B
\end{tabular}

Source: Bank Indonesia, 2017b; Bloomberg, 2017.

Based on Table 2, it can be seen that the probability $t$-value of all regression coefficients used in the White test for JCI regression equation and JII regression equation has a value greater than $5 \%$. Based on this, it is concluded that there is no heteroscedasticity on JCI and JII regression equation.

\section{Autocorrelation Test Results}

The autocorrelation test was performed using Durbin Watson test. The Durbin Watson test results can be seen in Table 3. The DW-values for JCI and JII regression equations are 1.847 and 1.940 , respectively, in the range of dU (1.747) to 4-dU (2.253). Based on this it can be concluded that there is no autocorrelation in both regression equations used in this study.

Table 3

Durbin Watson Test Results For JCI and JII Regression Equations

\begin{tabular}{lcccc}
\hline $\begin{array}{c}\text { Regression } \\
\text { Equation }\end{array}$ & $\begin{array}{c}\text { DW- } \\
\text { Value }\end{array}$ & $\mathrm{dL}$ & $\mathrm{dU}$ & Conclusion \\
\hline JCI & 1.847 & 1.637 & 1.747 & No Autocorrelation \\
JII & 1.940 & 1.637 & 1.747 & No Autocorrelation \\
\hline
\end{tabular}

Source: Bank Indonesia, 2017b; Bloomberg, 2017.

\section{Results of Multiple Regression Analysis}

Based on the results of classical assumption test that has been done then it can be concluded that there is no violation of classical assumption in the regression equation produced so that the regression equation can meet the criteria of the best linear unbiased estimator. The results of multiple regression analysis can be seen in Table 4 and Table 5.

Table 4

Results of Multiple Regression Analysis with JCI As Independent Variable

\begin{tabular}{lccc}
\hline & $\begin{array}{c}\text { Unstandardized } \\
\text { Coefficient }\end{array}$ & $\begin{array}{c}\text { Standardardized } \\
\text { Coefficient }\end{array}$ & $t$ \\
\hline Constant & 0.101 & & $3.225^{*}$ \\
GOLDIDR & 0.102 & 0.094 & 1.345 \\
USDIDR & -1.211 & -0.682 & $-9.555^{*}$ \\
BI & -15.290 & -0.191 & $-2.807^{*}$ \\
$R$ Square & 0.521 & & \\
$F$ & $39.158^{*}$ & & \\
\hline
\end{tabular}

Source: Bank Indonesia, 2017b; Bloomberg, 2017.

Information: *significant at a significance level of $1 \%$

Table 5

Results of Multiple Regression Analysis with JII as Independent Variable

\begin{tabular}{lccc}
\hline & $\begin{array}{c}\text { Unstandardized } \\
\text { Coefficient }\end{array}$ & $\begin{array}{c}\text { Standardardized } \\
\text { Coefficient }\end{array}$ & $\boldsymbol{t}$ \\
\hline Constant & 0.115 & & $2.955^{* *}$ \\
GOLDIDR & 0.182 & 0.159 & $1.927^{*}$ \\
USDIDR & -0.984 & -0.522 & $-6.213^{* *}$ \\
BI & -18.658 & -0.220 & $-2.741^{* *}$ \\
$R$ Square & 0.336 & & \\
$F$ & $18.233^{* *}$ & & \\
\hline
\end{tabular}

Source: Bank Indonesia, 2017b; Bloomberg, 2017.

Information: *significant at a significance level of $10 \%$

**significant at a significance level of $1 \%$ 
Based on the result of multiple regression analysis can be formed regression equation as follows:

For JCI,

$\Delta \mathrm{JCI}_{t}=0.101+0.102 \Delta \mathrm{GOLDIDR}_{t}-1.211 \Delta \mathrm{USDIDR}_{t}-$ $15.290 \mathrm{BI}_{t}+e$

Whereas,

$\triangle \mathrm{JCI}_{t} \quad: \mathrm{JCI}$ return in month $t$

$\triangle \mathrm{GOLDIDR}_{t}$ : change of gold price (in Rupiah Currency) in month $t$

$\Delta \mathrm{USDIDR}_{t}:$ : change of USD/IDR exchange rate in month $t$

$\mathrm{BI}_{t} \quad:$ BI rate in month $t$

$e \quad:$ error

For JII,

$\Delta \mathrm{JI}_{t}=0.115+0.182 \Delta \mathrm{GOLDIDR}_{t}-0.984 \Delta \mathrm{USDIDR}_{t}-$ $8.658 \mathrm{BI}_{t}+e$

Whereas,

$\Delta \mathrm{JII}_{t} \quad:$ JII return in month $t$

$\Delta$ GOLDIDR $_{t}$ : change of gold price (in Rupiah Currency) in month $t$

$\Delta \mathrm{USDIDR}_{t}$ : change of USD/IDR exchange rate in month $t$

$\mathrm{BI}_{t} \quad:$ BI rate in month $t$

$e \quad:$ error

The value of GOLDIDR regression coefficient on JCI equation is 0.102 with a $t$-value of 1.345 which is not significant. Based on this, $\mathrm{H}_{1 \mathrm{a}}$, which states that the gold price has a positive effect on the Jakarta Composite Index (JCI), is rejected. But different things are found in JII equation. The value of the regression coefficient of GOLDIDR in the JII equation is 0.182 with the $t$-value of 1.927 which is significant at the 5\% significance level. Based on this case $\mathrm{H}_{1 b}$ stating that the price of gold has a positive effect on the Jakarta Islamic Index (JII), cannot be rejected. These findings suggest that gold can serve as a diversifier for JCI. Baur and Lucey (2010) argue that an asset can function as a diversifier for the stock market if it has a non-significant positive relationship with the stock market. It also supports various findings on the potential for gold to be a diversifier for the stock market that has been done by Ghazali, Lean, and Bahari (2013); Ghazali, Lean, and Bahari (2015); Hoang, Lean, and Wong (2015); Ibrahim and Baharom (2012); Robiyanto et al. (2017b). Meanwhile, the finding that gold has a significant positive effect on JII provides empirical evidence supporting research done by Irianto (2002) and Hussin, Muhammad, Awang, Marwan, and Razak (2013) which says gold is the instrument most often associated with sharia investment. But on the other hand, it also shows that gold cannot function as hedge or diversifier for JII.
The value of the USD/IDR regression coefficient on the JCI equation is -1.211 with a $t$-value of -9.555 which is significant at $1 \%$ significance level. Based on this, $\mathrm{H}_{2 \mathrm{a}}$ which states that the USD/IDR exchange rate has a negative effect on the Jakarta Composite Index (JCI), cannot be rejected. The same is true of the value of the USDIDR regression coefficient on the JII equation whose magnitude is -0.984 with a $t$ value of -6.213 which is significant at a significance level of $1 \%$. Based on this, $\mathrm{H}_{2 \mathrm{~b}}$, which states that the USD/IDR exchange rate has a negative effect on the Jakarta Islamic Index (JII), it cannot be rejected. This is consistent with the results of the results of Gumilang et al. (2014); Irianto (2002) and Uligoma (2014). These findings suggest that the higher rate of USD/ IDR exchange rate changes will further decrease JCI and JII.

The value of BI regression coefficient on JCI equation is -15.290 with $t$-value counted -2.807 which is significant at $1 \%$ significance level. Based on this, $\mathrm{H}_{3 \mathrm{a}}$ which states that $\mathrm{BI}$ rate has a negative effect on the Jakarta Composite Index (JCI), cannot be rejected. The same thing also happened to the value of $\mathrm{BI}$ regression coefficient on JII equation whose magnitude is - 18.658 with $t$-value equal to 2.741 which is significant at $1 \%$ significance level. Based on this, $\mathrm{H}_{3 \mathrm{~b}}$, which states that BI rate has a negative effect on the Jakarta Islamic Index (JII), cannot be rejected. These findings are consistent with the results of Irianto (2002); Kurniawati (2015) and Gumilang et al. (2014). This indicates that the increasing BI rate will cause a decrease in JCI and JII.

The independent variables that have the most dominant influence on JCI and JII are USDIDR, followed by BI and GOLDIDR. Meanwhile, the coefficient of determination showing the ability of independent variables in the JCI equation to explain the amount of variation in JCI return is $52.1 \%$, whereas the coefficient of determination showing the ability of independent variables in the equation JII to explain the amount of variation in JII return is equal to $33.6 \%$. The JCI and JII regression equations yield significant $F$-value at the $1 \%$ significance level. This shows that $\mathrm{JCI}$ and JII regression equations are suitable for use.

\section{Conclusion and Implication}

The results of this study indicate that changes in USD/IDR rate and $\mathrm{BI}$ rate have a significant negative effect on JCI return. Furthermore, the results of this study also show that changes in USD/IDR rate and BI rate have a significant negative effect on JII return, while changes in the price of gold in the currency of Rupiah has a positive influence on JII return. The 
positive influence of this gold price change on the JII return can occur because as a stock price index formed from sharia stocks, JII becomes an indicator of sharia-based investment in Indonesia Stock Exchange, and sharia investment, in general, is strongly associated with gold. Changes in USD/IDR exchange rates have the most dominant influence on JCI and JII returns compared to BI rate and gold price changes.

The findings in this study imply that investors in the Indonesia Stock Exchange should pay attention to changes in USD/IDR rate and $\mathrm{BI}$ rate. If there is a strengthening of the USD/IDR rate, then investors are better to sell their stocks because the strengthening of the USD/IDR exchange rate will decrease both JCI and JII returns, the same is necessary if there is an increase in BI rate. Especially for sharia stock investors, it is advisable to pay attention to the movement of gold price due to the change of gold price will cause the increasing return of sharia stocks that enter into the calculation of JII.

Future research is recommended to use a longer period of research to know the impact of the variables studied on JCI and JII in the long run. Future research can also examine other stock indices in Indonesia Stock Exchange or can analyze for each stock.

\section{References}

Ang, R. (1997). Buku pintar pasar modal Indonesia. Jakarta: Mediasoft Indonesia.

Atmadja, A. S. (2002). Analisa pergerakan nilai tukar rupiah terhadap dolar amerika setelah diterapkannya kebijakan sistem nilai tukar mengambang bebas di Indonesia. Jurnal Akuntansi dan Keuangan, 4(1), 69-76.

Batten, J. A., Ciner, C., \& Lucey, B. M. (2010). The macroeconomic determinants of volatility in precious metals markets. Resources Policy, 35(2), 65-71.

Baur, D. G. \& Lucey, B. M. (2010). Is gold a hedge or a safe haven? An analysis of stocks, bonds and gold. The Financial Review, 45, 217-229.

Baur, D. G., \& McDermott, T. K. (2009). Is gold a safe haven? International evidence. Journal of Banking and Finance, 34(8), 1886-1898.

Beckmann, J. \& Czudaj, R. (2012). Gold as an inflation hedge in a time-varying coefficient framework. RUHR Economic Papers (362).

Bank Indonesia (2017a). BI 7-day (reverse) repo rate. Retrieved October 17, 2017, from http:// www. bi.go.id/id/moneter/bi-7day-RR/data/Con-tents/ Default.aspx.
Bank Indonesia (2017b). BI rate. Retrieved October 13, 2017, from http://www.bi.go.id/id/moneter/ bi-rate/data/Default.aspx.

Bloomberg (2017). Market data. Retrieved October 15, 2017, from https://www.bloomberg.com/.

Ernayani, R., Robiyanto, R., \& Sudjinan, S. (2017). Factors influencing profit distribution management of sharia commercial banks in Indonesia. Journal of Economics, Business \& Accountancy Ventura, 20(2), 187-192.

Ernayani, R., Sari, O., \& Robiyanto, R. (2017). The effect of return on investment, cash ratio, and debt to total assets towards dividend payout ratio (A study towards manufacturing companies listed in Indonesia stock exchange). Advanced Science Letters, 23(8), 7169-7199.

Ghazali, M. F., Lean, H. H., \& Bahari, Z. (2013). Is gold a hedge or a safe haven? An empirical evidence of gold and stocks in Malaysia. International Journal of Business and Society, 14(3), 428443.

-- (2015). Sharia compliant gold investment in Malaysia: Hedge or safe haven? Pacific-Basin Finance Journal, 34, 192-204.

Gumilang, R. C., Hidayat, R. R., \& NP, M. G. W. E. (2014). Pengaruh variabel makro ekonomi, harga emas dan harga minyak dunia terhadap indeks harga saham gabungan (Studi pada bursa efek indonesia periode 2009-2013). Jurnal Administrasi Bisnis, 14(2).

Haholongan, R. (2016). Kinerja lingkungan dan kinerja ekonomi perusahaan manufaktur go public. Jurnal Ekonomi dan Bisnis, 19(3), 413424.

Harmono, H. (2017). Relationship between macroeconomics fundamentals, bank credit scheme, firms performance, and firms value dimensions. Jurnal Keuangan dan Perbankan (JKP), 21(1), 82-94.

Hersugondo, S., Robiyanto, R., Wahyudi, S., \& Muharam, H. (2015). The world oil price movements and stock returns in several southeast asia's capital markets. International Journal of Applied Business and Economic Research, 13 (2), 527-534.

Hoang, T. H. V., Lean, H. H., \& Wong, W. K. (2015). Is gold good for portfolio diversification? a stochastic dominance analysis of the paris stock exchange. International Review of Financial Analysis, 42, 98-108.

Hussin, M. Y. M., Muhammad, F., Awang, S. A., Marwan, N. F., \& Razak, A. A. (2013). The dynamic interaction between islamic stock market and strategic commodities. Journal of Islamic Economics, Banking and Finance, 9(3), 5368. 
Ibrahim, M. H. (2012). Financial risk market and gold investment in an emerging market: The case of Malaysia. International Journal of Islamic and Middle Eastern Finance and Management Research News, 5(1), 25-34.

Ibrahim, M. H. \& Baharom, A. H. (2011). The role of gold in financial investment: A Malaysian perspective. Economic Computation and Economic Cybernetics Studies and Research, 45(4), 227238.

Irianto, G. (2002). Pengaruh bunga deposito, kurs mata uang, dan harga emas terhadap indeks harga saham gabungan (IHSG). Journal The Winners, 3(1), 1-10.

Joesoef, J. R. (2008). Pasar uang \& pasar valuta asing. Jakarta Salemba Empat.

Kumar, D. (2014). Return and volatility transmission between gold and stock sectors: Application of portfolio management and hedging effectiveness. IIMB Management Review, 26(1), 5-16.

Kurniawati, E. (2015). Analisis pengaruh nilai tukar (kurs) dolar Amerika/rupiah (us\$/rp), inflasi, bi rate, dan jumlah uang beredar terhadap harga saham pada perusahaan perbakan yang terdaftar di bursa efek Indonesia periode 2013. Skripsi, Universitas Muhammadiyah Surakarta, Surakarta.

Nuryadin, D. \& Santoso, B. (2004). Analisis aplikasi model neraca pembayaran dan model moneter terhadap nilai tukar rupiah/dolar, periode 1980.1 -2000.4. Buletin Ekonomi Moneter dan Perbankan, September, 273-296.

Robiyanto, R. (2017a). The analysis of capital market integration in asean region by using the OGARCH approach. Jurnal Keuangan dan Perbankan (JKP), 21(2), 169-175. (2017b). Performance evaluation and risk aversion rate for several stock indices in Indonesia stock exchange. Jurnal Manajemen dan Kewirausahaan, 19(1), 60-64.

Robiyanto, R., Wahyudi, S., \& Pangestuti, I. R. D. (2017a). Testing commodities as safe haven and hedging instrument on asean's five stock markets. Jurnal Ekonomi Kuantitatif Terapan, 10 (2), 110-252.

- (2017b). The volatility-variability hypotheses testing and hedging effectiveness of precious metals for the Indonesian and Malaysian capital markets. Gadjah Mada International Journal of Business, 19(2), 167-192.

Triyono, D. \& Robiyanto, R. (2017). The effect of foreign stock indexes and indonesia's macroeconomics variables toward Jakarta composite stock price index (JCI). Advanced Science Letters, 23(8), 7211-7214.

Tully, E. \& Lucey, B. M. (2007). A power GARCH examination of the gold market. Research in International Business and Finance, 21, 316325.

Uligoma, M. N. (2014). Identifikasi korelasi nilai tukar rupiah dan indeks harga saham gabungan melalui ensemble empirical mode decomposition. Skripsi, Institut Pertanian Bogor, Bogor.

Yuswandy, Y. (2013). Analisis pengaruh harga minyak dunia, harga emas dunia, nilai tukar RP terhadap USD dan indeks IHSG terhadap return saham (Studi kasus saham-saham Sinarmas Group). Working Paper. 